\title{
「ナノカーボン系材料のフィラーとしての展望」 特集号の企画にあたって
}

地球環境保全の立場から低炭素社会実現に向け て活発な動きが世界的に展開されています。ゴム やプラスチック製品製造においても，原料を石油 に依存しているためこの影響を強く受けています. また，石油燃料の有効活用には自動車を始めとし た輸送機器の軽量化やタイヤの高性能化が不可欠 であり，各種製品の環境適用にはゴムやプラスチ ックが大きく役立っています。さらに複合材料の 分野では, 複合化される無機化合物は比重が小さ く少量の充てんで性能や機能の大幅向上が期待で きるサイズの小さな材料（ナノ材料）が注目され ています。中でも炭素はゴムではなじみ梁いカー ボンブラックをはじめカーボンナノチューブ (CNT)，フラーレンなど，多様な結合形態や構造 からそれらがもつ幅広い機能が期待されています。 本特集の著者の竹内先生が記されておられるよう に,「ナノメータのレベルで精緻に微視的に構造や 組織・形態が制御，設計され，それによって従来 には無い高精度な性能が付与され，あるいは革新 的な機能を発現する炭素体」，すなわちナノカーボ ン系材料が新たなフィラーとして大きな期待を集 めています，材料の世界において，ナノカーボン 系フィラーとポリマーを複合化したコンポジット に代表されるように，積極的に炭素元素を活用し た炭素社会を構築することが低炭素社会実現に有 効であるという考えが有力になってきています.

ナノカーボン系フィラーの代表であるCNTはリ チウム電池の電極材料に実用化され，その高性能 化や新たな電子デバイスに用いる素材として注目
を集めています。一方, 充てん剂としてのナノカ ーボン材料の研究開発は, カーボンブラックやシ リカなどのこれまでの充てん剤に比較してそれを 分散させることの難しさから難易度が高くなって いますが，ナノカーボン充てん複合材料の飛躍的 な特性向上を目指し, 活発に繰り広げられていま す。近年，エラストマーをマトリックスとして CNTを充てんした場合に飛躍的な特性向上が可能 であることが見出され，さらに，導電性フィラー 用途として CNTの市場が拡大していることから CNTの量産化が世界各国で報じられています。

本特集では，このような現状を踏まえて，ナノ カーボン系材料の将来展望に関する特集号を企画 いたしました。はじめに，ナノカーボン材料の概 要, 応用例, 今後の展望について解説しています. 次に分散の難しいCNTの高分散化技術の一つであ るCNT 表面でのグラフト重合やCNT やフラーレ ンをフィラーとしてゴムに充てんした材料の卓越 した性能について解説しています，元素として炭 素を含んではいませんが, ナノカーボンと類似し た構造をもつ窒化ホウ素に関してはそのCNTを超 える特性を利用することによる高分子複合材料へ の展開や応用分野について解説しています.

最後になりましたが，本特集号にご寄稿いただ きました執筆者の皆様に心から御礼申し上げると ともに, 本特集号が会員皆様のお役に立つことを 祈念いたします。

（編集委員会・特集企画担当 永田 員也） 